\title{
Effect of fertilizer application schemes on wheat production. The case of Altai Krai
}

\author{
V.I. Belyaev ${ }^{1 *}$, D.V. Dubinin ${ }^{2}$, S.A. Ivanov ${ }^{3}$, V.N. Chernyshkov ${ }^{1}$, L.V. Sokolova ${ }^{4}$, A.V. \\ Matsyura $^{4}$
}

\author{
${ }^{1}$ Altai State Agrarian University, Barnaul, Russian Federation \\ ${ }^{2}$ FosAgro-Region Ltd, Moscow, Russian Federation \\ ${ }^{3}$ FosAgro-SeveroZapad Ltd, Cherepovets, Russian Federation \\ ${ }^{4}$ Altai State University, Barnaul, Russian Federation \\ Corresponding author e-mail: prof-belyaev@yandex.ru
}

Received: 21.07.2020. Accepted 30.09.2020

\begin{abstract}
Increasing of crop yields mainly caused by modern technology, use of mineral fertilizers and plant protection products. Therefore, developing of zonal agricultural technologies will ensure the rational use of soil agroclimatic potential and increase grain production profitability. Because of economic needs, the broad use of mineral fertilizers, including liquids with minor nutrient elements was applied in Altai Krai. Therefore, the justification of doses and sorts of fertilizers and minor nutrient elements is especially relevant here. The aim of our study was to increase the efficiency of granular and liquid mineral fertilizers in the cultivation of spring wheat in the steppe zone of Altai Krai. The experiment was done in LLC "Russia" in Novichikhinsky district of Altai Krai. We presents seven fertilizer variants for cultivating the spring wheat using the No-Till technology in the steppe zone of Altai region. We also assessed the quality of sowing, soil water regime, yield structure and grain quality, and presented the general patterns of crop formation and technical and economic evaluation of these fertilizer variants.
\end{abstract}

Key words: mineral fertilizers, No-Till technology, spring wheat, sowing quality, soil water regime, yield structure, grain quality, economic efficiency.

\section{Introduction}

Modern conditions for the development of agricultural production require efficiency of growing grain crops (Alexandratos, Bruinsma, 2012; Schierhorn et al., 2014; Bakaeva et al., 2019; Zimnyakov, Varlamova, 2020). Currently, many samples of new soil-cultivating sowing equipment of foreign and domestic production are used in Altai Krai, allowing to perform up to six operations per working pass, including the application of liquid and granular mineral fertilizers during the sowing (Belyaev, 2018). Therefore, we need to improve the grain crops cultivation technologies, the methods of applying granular and liquid fertilizers, and the formation of zonal technical and technological machine complexes, which will ensure the preservation and increase of soil fertility (Clay, Carlson, 2010; Belyaev, Sokolova, 2012, 2018; Belyaev et al., 2016). Analysis of agricultural crops cultivation technologies revealed the influence of climatic and technological factors on the yield and quality of grain (Belyaev et al., 2017a, 2017b, 2018). This will determine the rational technologies for cultivating crops by new equipment for effective fertilization, which would significantly increase the efficiency of crop production. Thus, the purpose of our study was to increase the efficiency of granular and liquid mineral fertilizers in spring wheat the cultivation in the steppe zone of the Altai Krai.

\section{Methods}

The experiment was done at Russia LLC, Novichikhinsky District, Altai Krai in 2019. Soil type - ordinary leached chernozem. Experiment started on May 12, 2019. Culture - spring wheat, "Thassos" variety. Dresser -"Scarlet", dose $0.4 \mathrm{Lt}^{-1}$. Preceding crop peas. Test plot size 18.9 ha. Autumn tillage was not carried out. On the surface of the field, there were crushed plant residues. During the growing season in the tillering phase, we used chemical treatments for plant protection: against the cereals - "Argo", dose $0.8 \mathrm{~L} \mathrm{ha}^{-1}$, against the broad-leaved plants - "Prima Donna", dose $0.8 \mathrm{~L} \mathrm{ha}^{-1}$. Fungicide "Title Duo", dose $0.4 \mathrm{~L}$ ha-1 . Against the thrips - "Espero", dose $0.1 \mathrm{~L} \mathrm{ha}^{-1}$. The plotting experiment is shown in Table 1.

Fertilizers were applied together with the seeds during sowing in rows and during vegetation fertilization in tillering stage according to experiment design. Sowing unit New Holland TJ380 tractor + Case IH Precision 30 pneumatic disc seeder with Case IH Precision Air cart, liquid fertilizer tank produced by LLC "Complex Agro" (Fig. 1). Seeding rate is 4.0 million ha ${ }^{-1}$, placement depth 4-5 $\mathrm{cm}$, row width $-20 \mathrm{~cm}$. Measurement parameters were presented in Belyaev, Makarov (2018).

The experiment was performed in scientific collaboration with FosAgro, who provided the fertilizers.

Table 1. Experiment variants 


\begin{tabular}{lcccc}
\hline 1 & CAM & 90 & UAN & 45 \\
2 & CAM & 90 & $U$ & 30 \\
3 & CAM+U & $90+30$ & - & - \\
4 & CAM+UAM & $90+45$ & - & - \\
5 & AN & 70 & - & - \\
6 & ADP & 70 & UAN & 50 \\
7 & ADP & 70 & U & 35 \\
\hline
\end{tabular}

AN - ammonium nitrate, CAM - liquid carbomide-ammonia mixture, ADP - ammophos (ammonium dihydrogen phosphate), UAM - urea-ammonia mixture; U - urea.

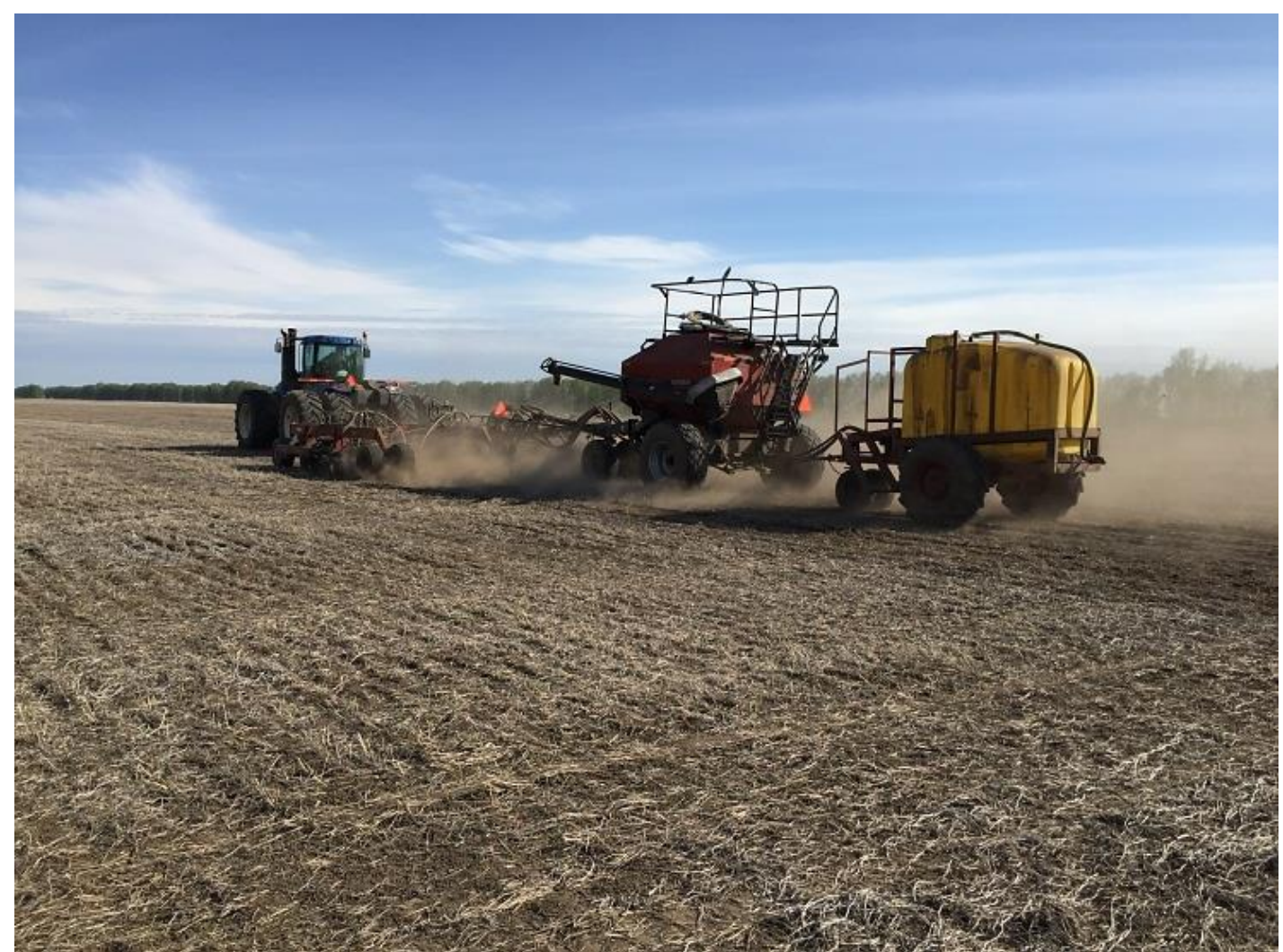

Fig. 1. Wheat planting and fertilizing.

Russia LTD is located in Rubtsovsko-Aleyskaya zone of Altai Krai, which characterized by certain climatic conditions (Tables 2-3).

Table 2. Amount of precipitation in the growing season, 2019 (according to the weather station near Pospelikha village)

\begin{tabular}{|c|c|c|c|c|c|c|}
\hline Month & \multicolumn{3}{|c|}{ Decade precipitation sum, mm } & $\begin{array}{c}\text { Total } \\
\text { precipitation, } \\
\mathrm{mm}\end{array}$ & $\begin{array}{c}\text { Average annual } \\
\text { precipitation, } \\
\text { mm }\end{array}$ & $\begin{array}{c}\% \text { from } \\
\text { average annual } \\
\text { precipitation }\end{array}$ \\
\hline May & 4 & 7 & 4 & 15 & 37 & 41 \\
\hline June & 27 & 42 & 19 & 88 & 42 & 210 \\
\hline July & 1 & 3 & 29 & 33 & 58 & 57 \\
\hline Total & - & - & - & 150 & 177 & 85 \\
\hline
\end{tabular}

Table 3. Average temperatures during the growing season, 2019 (according to the weather station near Pospelikha village)

\begin{tabular}{lcccccc}
\hline Month & I & $\begin{array}{c}\text { Decade average T, }{ }^{\circ} \mathrm{C} \\
\text { II }\end{array}$ & & III & $\begin{array}{c}\text { Mean T, } \\
{ }^{\circ} \mathrm{C}\end{array}$ & $\begin{array}{c}\text { Mean } \\
\text { multiannual } \\
\mathrm{T},{ }^{\circ} \mathrm{C}\end{array}$ \\
& & & & $\begin{array}{c}\% \text { from } \\
\text { multiannual } \\
\text { mean T }\end{array}$ \\
\hline May & 12.4 & 9.7 & 13.7 & 12.0 & 12.9 & 93 \\
June & 17.2 & 16.9 & 17.5 & 17.2 & 18.7 & 92 \\
July & 20.5 & 21.7 & 20.3 & 20.8 & 20.6 & 101 \\
August & 23.3 & 20.0 & 18.5 & 20.5 & 17.9 & 115 \\
Mean & - & - & - & 17.6 & 17.5 & 101 \\
\hline
\end{tabular}


Thus, in May - August months the amount of precipitation in the conditions of the year was 27.0 mm (15.3\%) lower than the longterm average, and the average temperature is higher by $0.1^{\circ} \mathrm{C}(0.6 \%)$. Moreover, if in June precipitation was 2.1 times higher than normal, in May, July and August - only 35-57\% of the norm. June was the coldest month (average temperature was $92.0 \%$ of the norm), and August was warmest (114.5\% of the norm). As of May 12, the soil humidity and moisture reserves by layers up to 1 $\mathrm{m}$ were distributed as follows (Table 4).

Table 4. Soil moisture and moisture reserves (up to $100 \mathrm{~cm}$ ).

\begin{tabular}{|c|c|c|c|c|c|c|c|c|c|}
\hline \multicolumn{10}{|c|}{ Soil layer $(\mathrm{cm})$} \\
\hline $0-10$ & $10-20$ & $20-30$ & $30-40$ & $40-50$ & $50-60$ & $60-70$ & $70-80$ & $80-90$ & $90-100$ \\
\hline \multicolumn{10}{|c|}{ Moisture (\%) } \\
\hline 23.6 & 21.9 & 25.4 & 25.5 & 24.7 & 22.6 & 21.8 & 22.0 & 20.3 & 21.2 \\
\hline \multicolumn{9}{|c|}{ Soil layer (cm) } & $0-100$ \\
\hline \multicolumn{10}{|c|}{ Soil moisture reserve $(\mathrm{mm})$} \\
\hline 23.6 & 45.5 & 70.9 & 96.4 & 121.1 & 143.7 & 165.6 & 187.5 & 207.8 & 229.0 \\
\hline
\end{tabular}

The total moisture reserves in the meter layer of soil were $229.0 \mathrm{~mm}$. The soil of the experimental field had the following basic parameters: nitrogen - high content, phosphorus - high, potassium - high, humus - low content. The reaction of the soil was weakly acidic.

\section{Results}

The average placement depth of wheat seeds at the plots was within 31.6-47.4 mm with standard deviations of $10.0-14.0 \mathrm{~mm}$ and variations of $25.8-33.0 \%$. On the average, by comparable variants, the seed insertion depth was $39.8 \mathrm{~mm}$, the deviation was 11.9 $\mathrm{mm}$, and the variation was $30.3 \%$. In other words, the seed placement uniformity was not high.

The average number of seedlings by the variants of experiments varied from $335.3 \mathrm{pcs} . / \mathrm{m}^{2}$ (variant 7 ) to $355.5 \mathrm{pcs} . / \mathrm{m}^{2}$ (variant 5 ) with the average value of $345.3 \mathrm{pcs} . / \mathrm{m}^{2}$. Field germination capacity of wheat seeds at the plots varied within narrow limits: from $83.8 \%$ (plot 7) to $88.9 \%$ (plot 5). The average yield of comparable fertilizers was $86.3 \%$, with a deviation of $2.0 \%$ and variations of only $2.7 \%$. The number of surviving plants for harvest was $163.2 \mathrm{pcs} / \mathrm{m}^{2}$ (Variant 6) to $182.3 \mathrm{pcs} / \mathrm{m}^{2}$ (Variant 3). The average value was $171.9 \mathrm{pcs} . / \mathrm{m}^{2}$ with a variation of $3.7 \%$. Preservation of wheat plants for harvesting by variants was low and varied in the range from $46.0 \%$ (variant 6) to $55.7 \%$ (variant 3). On average, it was $50.7 \%$ with variation of $6.1 \%$. As a result, the number of productive stems by variants of experiments differed from $286.9 \mathrm{pcs} / \mathrm{m}^{2}$ (variant 6) to $305.9 \mathrm{pcs} / \mathrm{m}^{2}$ (variant 1 ). The average value was $294.3 \mathrm{pcs} . / \mathrm{m}^{2}$ with variation of $2.0 \%$. Productive shrubbery of plants by variants was on the average 1.73 with changes from 1.67 (variant 3) to 1.77 (variants 1,6 and 7 ) and total variation of $2.4 \%$.

Thus, the fertilizer variants had the largest impact on plant safety for harvest (6.1\% of variation). Plant development phases and test variants differed significantly in moisture consumption from a meter layer of soil. As a result, the soil moisture consumption in 1 $\mathrm{m}$ of soil was the highest in variants $1(117.5 \mathrm{~mm})$ and $7(117.2 \mathrm{~mm})$ during the vegetation period, while in variant $6(101.6 \mathrm{~mm})$ it was the lowest. The differences were significant. The total average moisture consumption from a meter layer of soil per unit of biological yield of wheat varied from $3.72 \mathrm{~mm} \mathrm{c}^{-1}$ (per centner, variant 4) to $4.50 \mathrm{~mm} \mathrm{c}^{-1}$ during the vegetation (variant 5). The average moisture consumption per unit of physical yield of wheat at the plots ranged from 4.20 (variant 6 ) to $5.07 \mathrm{~mm} \mathrm{c}^{-1}$ (variant 5). The average moisture consumption per unit of biological and harvesting wheat was $4.1 \mathrm{~mm}$ per centner, respectively.

In terms of total wheat plant biomass, number of productive stems, ear weight and biological yield, the variant $1\left(81.1 \mathrm{c}\right.$ ha ${ }^{-1}, 305.1$ $\mathrm{pcs} / \mathrm{m} 2,38.5 \mathrm{c} \mathrm{ha}^{-1}$ and $\left.28.1 \mathrm{c} \mathrm{ha}^{-1}\right)$ and $4\left(81.9 \mathrm{c} \mathrm{ha}^{-1}, 297.3 \mathrm{pcs} / \mathrm{m} 2,42.7\right.$ and $\left.31.2 \mathrm{c} \mathrm{ha}^{-1}\right)$ had the great advantage. By weight of ear and grain in it - variant 2 and $7(1.70$ and $1.29 \mathrm{~g} ; 1.73$ and $1.28 \mathrm{~g}$ respectively). By number of grains per ear, the highest value had variant 7 (37.1 pcs.). Variant 5 (70.1 centners $/ \mathrm{m}^{2}, 291.4 \mathrm{pcs} / \mathrm{m}^{2}, 34.6$ and $25.2 \mathrm{c} \mathrm{ha} \mathrm{C}^{-1}$ respectively) was the best in terms of biomass, number of productive stems, ear mass and biological yield. Individual elements of wheat yield structure had different variability: the minimum value corresponded to the number of productive stems and height of plants ( $2.1 \%$ and $2.8 \%$ respectively), whereas the maximum value - to the mass of ears and grains per ear, the mass of ears and yield, and total plant biomass (6.9\% and $9.1 \%, 6.9 \%$ and $7.0 \%, 5.8 \%$ respectively).

Maximum protein and gluten content in grain was obtained in variant 5 (15.6 and 35.2\%, respectively), and the worst quality was observed in variants 2, 3 and 7 (protein 14.3-14.5\%, gluten 31.7-31.9\%). In general, high quality grain was obtained in next sowing variants: protein content $-14.9 \%$, gluten $-33.2 \%$. The used fertilizer variants had the greatest impact on the variability of protein and gluten in wheat grains. Their variability was 3.8 and $4.4 \%$, respectively, while the IIR and grain nature were $2.7 \%$ and $0.8 \%$, respectively. Physical yields at the plots varied from $23.4 \mathrm{c} \mathrm{ha}^{-1}$ (variant 5) to $28.1 \mathrm{c} \mathrm{ha}^{-1}$ (variant 1 ). There were differences between variants 1,4 and 7 in terms of measurement error, and between variants 2 and 6,3 and $6\left(\operatorname{LSD}_{0.05}=0.7 \mathrm{c} \mathrm{ha}{ }^{-1}\right)$. In terms of biological and harvesting yields of wheat, variants 1 (28.0 and $\left.26.6 \mathrm{c} \mathrm{ha}^{-1}\right)$ and $4\left(31.1\right.$ and $\left.26.1 \mathrm{c} \mathrm{ha}^{-1}\right)$ had a reliable advantage. Variant 5 (25.1 and $22.3 \mathrm{c} \mathrm{ha}^{-1}$ ) was significantly inferior to all the others. The average grain loss during harvesting was $2.2 \mathrm{c}$ ha ${ }^{-1}$ or $8.8 \%$.

Analysis of soil supply with elements of mineral nutrition of plants showed that there is significant direct linear connection between combine yield of wheat and sum of absorbed bases $(R=0.81)$. Feedback of biological and harvest wheat yield with cation exchange capacity has been determined $(R=-0.82$ and $R=-0.91$ respectively). The same character of connection of yield with degree of saturation of bases $(R=-0,81$ and $R=-0,79$ correspondingly).

The technical and economic assessment of comparable fertilizer variants was based on fertilizer costs, wheat yield and grain quality. The calculations were based regards the variants of combine yield of spring wheat, normalized to $12.0 \%$ of grain moisture content, fertilizer purchase prices by group and crop sale prices, taking into account the grain grade. The minimum fertilizer cost was set at variant 5 ( 977.2 \& per hectare, ammonium nitrate).

In variants $1-4$, the fertilizer costs were 2,277-2,759 \& ha ${ }^{-1}$, while in variants 6 and 7 they were 2,548-2,613 f ha ${ }^{-1}$, respectively. The maximum yield was obtained in variants 1 and $4\left(40,876-40,108\right.$ \& ha ${ }^{-1}$, respectively), with the respective yield and cost differences of 38,149 and $37,381 \mathrm{~F}$. This, these variants provide the best fertilizer efficiency indicators. Compared to the control (variant 5), the variants 1 and 4 yielded 4,858 and $4089 \mathrm{P} \mathrm{ha}^{-1}$, respectively. Application of fertilizer variants 6 and 7 resulted in 
higher revenues compared to control by 1,349 and 2,462 f respectively, while variants 2 and 3 resulted in lower revenues by 1,738 and $290 \mathrm{P}$ respectively. Economic calculations showed that the highest efficiency of fertilizer application, compared to control (ammonium nitrate), was achieved in variants 1 (liquid carbomide-ammonia mixture $90 \mathrm{~kg} \mathrm{ha}^{-1}$ at planting + urea-ammonia mixture $45 \mathrm{~kg} \mathrm{ha}^{-1}$ at vegetation) and 4 (liquid carbomide-ammonia mixture $90 \mathrm{~kg} \mathrm{ha}^{-1}+$ urea-ammonia mixture $45 \mathrm{~kg} \mathrm{ha}^{-1}$ at planting).

\section{References}

Alexandratos, N. and Bruinsma, J. (2012). World agriculture towards 2030/2050: the 2012 revision. ESA Working paper No. 12-03. Rome, FAO.

Bakaeva, N.P, Saltykova, O.L., Korzhavina, N.Yu. and Prikazchikov, M.S. (2019). Economics of spring wheat production in the Middle Volga. IOP Conf. Series: Earth and Environmental Science 315, 022056. doi:10.1088/1755-1315/315/2/022056.

Belyaev, V.I. (2018). The effectiveness of the use of granular and liquid mineral fertilizers with microelements in the cultivation of spring wheat in the Kulunda steppe of the Altai Territory. All-Russian Sc. Conf. "Prospects for the introduction of innovative agricultural technologies in the cultivation of agricultural crops". (November 23, 2018). Barnaul. RIO Altai State Agrarian Univerity (in Russian).

Belyaev, V.I., Mainel, T., Grunwald, L., Schmidt, G., Bondarovich, A.A., Rudev N.V. (2016). The water regime of the soil and the yield of agricultural crops with various cultivation technologies in the Kulunda steppe of the Altai Territory. Bulletin of the Dnipropetrovsk University. Biology. Ecology, 24(2), 531-539.

Belyaev, V.I., Makarov, G.A. (2018). Agronomic efficiency of the use of mineral fertilizers in the Eastern zone of the Altai Territory. Bulletin of the Altai State Agrarian University, 10(168), 32-39 (in Russian).

Belyaev, V.I., Meinel, T., Grunewald, H., Sokolova, L.V., Kuznetsov, V.N., Matsyura, A.V. (2018). Influence of spring soft wheat, peas and rape cultivation technology on soil water regime and crop yield. Ukrainian Journal of Ecology, 8(1), 873-879.

Belyaev, V.I., Rudev, N.V., Maynel, T., Kozhanov S.A., Sokolova L. V., Matsyura, A.V. (2017b). Effect of sowing aggregates for direct sowing, sowing seeding rates and doses of mineral fertilizers on spring wheatyield in the dry steppe of Altai Krai. Ukrainian Journal of Ecology, 7(4), 145-150.

Belyaev, V.I., Sokolova, L.V. (2012). Yield of spring soft wheat depending on the variety and dose of fertilization. Bulletin of the Altai State Agrarian University, 12(98), 21-24 (in Russian).

Belyaev, V.I., Sokolova, L.V. (2018). The influence of the seeding rate of seeds and the dose of fertilization on the yield of spring wheat in the conditions of the Altai Ob region. Bulletin of the Altai State Agrarian University, 9(167), 10-22 (in Russian).

Belyaev, V.I., Vol'nov, V.V., Sokolova, L.V., Kuznecov, V.N., Matsyura, A.V. (2017a). Effect of sowing techniques on the agroecological parameters of cereal crops. Ukrainian Journal of Ecology, 7(2), 130-136.

Clay, D.E., Carlson, C.G. (2010). Fertilizers used in wheat production. In: Clay, D.E., C.G. Carlson, and K. Dalsted (eds). iGrow Wheat: Best Management Practices for Wheat Production in South Dakota. South Dakota State University, South Dakota Cooperative Extension Service, Brookings, SD. Available from: https://www.researchgate.net/publication/283515466 Fertilizers Used in Wheat Production 1 Fertilizers Used In Wheat Production\#fullTe xtFileContent/

Schierhorn, F., Faramarzi, M., Prishchepov, A.V., Koch, F.J. and Daniel Müller, D. (2014). Quantifying yield gaps in wheat production in Russia. Environ. Res. Lett. 9, 084017. doi:10.1088/1748-9326/9/8/084017

Zimnyakov, V.M., Varlamova, E.N. (2020). Wheat production in Russia. Niva Povolzhya, 1(54), 12-21. doi:10.36461/NP.2020.54.1.003 (in Russian).

\section{Citation:}

Belyaev, V.I., Dubinin, D.V., Ivanov, S.A., Chernyshkov, V.N., Sokolova, L.V., Matsyura, A.V. (2020). Effect of fertilizer application schemes on wheat production. The case of Altai region. Ukrainian Journal of Ecology, 10(4), 269-272.

(cc) $\mathrm{EY}$ This work is licensed under a Creative Commons Attribution 4.0. License 